\title{
Effects of Information and Communication Technologies on the Banks' Production Level in West African Economic and Monetary Union
}

\author{
Moussa Coulibaly \\ Department of Economics and Management, Université Ouaga II, Ouagadougou, Burkina Faso
}

\begin{abstract}
The paper specifically analyzed the effects of information and communication technologies on the banking production in the West African Economic and Monetary Union. It thus provides new empirical evidence on this subject in an area where such a problem is poorly explored in the literature. A Cobb-Douglas production model on panel data was used to analyze the elasticity of production of banks in the Union in relation to their technological capital over the period 2010-2016. The panels corrected standard errors method was favored for estimating model. The results indicate that automatic teller machines directly improve the level of production of banks in the West African Economic and Monetary Union. This research therefore encourages all measures aimed at strengthening their use by banks in the Union.
\end{abstract}

Keywords: Banks, banking production, ICT

DOI: $10.7176 / \mathrm{JESD} / 11-12-12$

Publication date:June 30th 2020

\section{Introduction}

In the New York Times book review in 1987, Robert Solow said, «You can see the computer age everywhere but in the productivity statistics». The author argued that information and communication technologies (ICT) have no effect on the economic performance of the countries that use them. This point of view of the author will constitute, mainly, the starting point for theoretical and empirical analyses of the effects of ICT on the performance of user enterprises or on the performance of countries using these technologies. Indeed, Solow (1987) finding appears paradoxical in reference to Schumpeter $(1911,1939)$ works, on the basis of which it is widely accepted in the literature that technological innovations play a major role in explaining changes in the level and output of firms, economic growth and even the economic development of countries. Thus, on the basis of Schumpeter $(1911,1939)$ works, it was logical to expect that ICT would play an important role, from their inception, in the general performance of firms or in the performance of the countries that use them.

Currently, a review of the literature on the effects of ICT on the performance of firms that use them or on the performance of countries that use them shows that Solow (1987) does not have a consensus view in the general literature. In the manufacturing sector, Gordon's (2000) analysis confirms Solow's paradox while other works refute it (Hall et al, 2012; Alderete et Gutiérrez, 2012; Donati et Sarno, 2013; Mitra et al, 2016). In the banking sector in particular, some empirical analyzes confirm Solow's paradox (Akhisar et al, 2015; Beccalli, 2007; Ho and Mallick, 2010) while others refute it (Mehmood et al, 2015; and Ogunyomi and Obi, 2016). The consequence of these results, which are controversial in the literature, is that the issue of the existence of ICT effects on banking performance in general remains topical. This issue still needs to be addressed in light of the increasing use of ICT by banks in their business, despite the controversy over their empirical effects on banking performance.

More specifically, in the WAEMU1 banking sector, traditional banks are turning more towards the adoption and use of ICT to provide banking services to the population. They are investing more in the installation and operation of automated teller machines (ATMs) to automate the banking services to customers. Over the period 2010-2016, the number2 of ATMs in the Union increased from 1178 in 2010 to 3010 in 2016, an increase of almost $155 \%$ in the space of 6 years. Today, e-banking is also a reality in the Union banking sector. Through mobile applications and the internet, bank customers have the possibility to carry out a number of online banking services.

Based on the unified theoretical analysis of Venkatesh et al (2003) on the adoption and use of information technology, it can be noted that banks in the Union would only have committed to using ICT to provide banking services to the population if they did not expect these ICT to improve their performance. This commitment by the WAEMU banking sector to more digitalization of banking services to the population is, however, taking place in a context where the empirical effects of ICT on the general performance of banks are not unanimously accepted in the literature. This state of affairs makes it impossible to know in advance, without an in-depth analysis, the effects of the process of digitization of banking services, to which WAEMU banks are committed, on banking performance in the Union.

To this end, this research focuses in particular on the effects of ICT on the level of production of banks in the WAEMU. In line with the Schumpeterian theory of innovation, this research assumes that the use of ATMs improves the level of output of banks in the WAEMU. The aim of this research is to analyze the effects of the use 
of ATMs on the level of output of banks in the Union.

The remainder of the article begins with a review of the literature. A third point presents the method of analysis. The results and their interpretations are the subject of the fourth section. The fifth section presents the conclusion and implications of the results.

\section{Literature review}

This research draws its theoretical foundations from three main theories that support a relationship between information technology and the general performance of user companies. These are the innovation theory of Schumpeter (1939), the unified theory of information technology adoption and use of Venkatesh et al (2003), and the production function framework proposed by Solow (1956).

The analysis of Schumpeter (1939) is in line with business cycle theories that seek to provide an explanation of the various recurring and persistent variations in economic activity. In his version of the theory of cycles, Schumpeter (1939) places the technological waves at the heart of the fluctuations of the capitalist economy but also at the origin of the various industrial revolutions in economic history. In terms of the economic cycle, the expansion phase results from the emergence of a new technological cluster with the corollary of improved productivity gains and the production of new products. The recession phase, as well as the subsequent contraction phase, occurs once these technology clusters reach maturity, leading to overproduction and falling prices, which in turn triggers the crisis. The resumption of a new cycle will be the result of new technological innovation.

This is how Schumpeter (1939) makes each Nicolas Kondratieff's long cycle correspond to a technological innovation that would be at its origin. According to Schumpeter's logic, ICT will play an important role in the evolution of economic activity during the first half of the $21^{\text {st }}$ century through their impact on the productivity gains of economies. At the level of the banking sector in particular, ICT offer banks opportunities for product innovation and, above all, process innovation. Product innovation refers to the creation of new products or services using ICT (Algan et al, 2016). According to the same authors, process innovation allows the adoption of new methods or the considerable improvement of old ones in the production or distribution of already existing products or services.

The use of ATMs and e-banking by traditional banks in the Union is part of this process innovation in the production and distribution of banking services through ICT. The use of ATMs and e-banking by traditional banks in the Union is part of this process of process innovation in the production and distribution of banking services using ICT. ATMs allow banks to be closer to the population in the provision of banking services in certain areas without necessarily having to set up a bank branch, which is generally more expensive. The automated operation of ATMs allows banks to offer a number of banking services to the population in a discontinuous manner over time, thus increasing their capacity to produce banking services. E-banking can also enhance the productive capacity of banking services to populations by enabling banks to offer certain banking services to populations in a discontinuous manner in time and space, as long as these populations have access to the Internet. ICT are also cited as a means of reducing banking transaction costs (Daley, 2003; El Fidha and Charki, 2008). In this sense, they are likely to reduce the overall level of banks' operating costs, thereby alleviating the banks' overall production constraint.

The unified theory of IT acceptance and use of Venkatesh et al (2003) provides an understanding of the determinants of IT adoption, diffusion and use. It is a synthesis of eight other major theories of information technology adoption, diffusion, or use, including Davis's (1989) technology acceptance model and Rogers's (1962) theory of diffusion of innovation. This unified theory suggests that one of the main determinants of a user's adoption and use of a technology is the performance expected from the use of that technology. In line with this theory, it can be argued that the adoption and use of ICT by banks in the WAEMU is partly motivated by the performance that each of these banks intends to derive from their use. Therefore, it can be inferred that the reason why banks are investing more in the installation and operation of ATMs in the Union is that they are partly guided by a certain belief that ATMs will improve their ability to provide banking services to the public.

Microeconomic theory of production, on the other hand, provides an ideal framework for the conceptual analysis of the effects of ICT on the level of output or on the level of factor or total productivity of firms. The production function of Solow (1956) is central to this analysis. ICT can affect the level of output or the level of productivity and, hence, the performance of a user firm in three ways. It can do so by acting on the autonomous factor of production or by acting as a third factor of production alongside the two classical factors. In both cases, they are considered as autonomous technological progress. They can also do so by acting on the productivity of at least one of the conventional factors of production (labor and capital) as embodied technology. In this research, ATMs are incorporated alongside labor and non-technological physical capital as a third factor of production in the banks' production function. The reason is that ATMs constitute technological capital that participates in the production process of banks as a complement or substitute for conventional factors of production.

Empirical research has already focused on the banking sector to analyze the effects of ICT on the level of output or profitability of banks. The findings of some of this work are being mobilized in order to allow for an in- 
depth discussion of the results of this research at a later date.

To that end, it should be noted that, to assess the effects of ICT in the banking sector, Swierczek and Shrestha (2003) conducted a comparative analysis of the link between ICT and productivity in banks in Asia-Pacific and Japan. These authors found a positive influence of ICT on the productivity of banks on both sides. They also find that the influence of ICT on bank productivity is greater for Asia-Pacific banks than for Japanese banks. For Shu and Strassmann (2005), the marginal product of ICT is more important than the marginal product of other factors of production that they use in their analysis of a sample of 12 U.S. banks over the 1989-97 period. Thus, their conclusion negates Solow's (1987) paradox.

Beccalli (2007) has questioned whether ICT investment enhances bank performance. To answer this question, the author uses a sample of 737 European banks over the period 1995-2000. He examines ICT investment in aggregate and investment in computer hardware, computer software and computer services in detail. It concludes that there is a weak relationship between total investment in ICT and improvements in bank profitability or efficiency. He describes this as the profitability paradox. It also finds heterogeneous impacts of investments in hardware, software and IT services. While IT services positively influence bank performance, the author finds that investments in computer hardware and software reduce bank performance.

Martín-Oliver and Salas-Fumás (2008) use a sample of 200 Spanish banks representing 95\% of the Spanish banking system over the period 1983-2003. They conclude that the increase in the ICT capital stock explains one third of the increase in output of banks in Spain. The authors add that an additional investment of 1 million euros in ICT can be substituted for 25 employees. For these authors, Solow's (1987) paradox is invalidated in their context.

Ho and Mallick's (2010) research evaluates the impact of ICT on the U.S. banking industry using a sample of 68 banks over the period 1986-2005. Their results suggest that, at the individual level, bank profits may decline as a result of the adoption and diffusion of ICT investment. Thus, their results confirm the existence of a Solow (1987) profitability paradox at the level of their sample of banks.

The results that emerge from the analyses of Ibrahim and Muhammad (2013), Muhammad et al. (2013) and Ogunyomi and Obi (2016) in the Nigerian context contrast with the findings of Ho and Mallick (2010). Indeed, Ibrahim and Muhammad (2013) analyzed the relationship between ICT and the performance of commercial banks in Nigeria over the period 2001-2011. Their findings suggest that wise use of ICTs by Nigerian banks will continue to improve their performance as long as the externalities arising from the use of ICTs in the banking sector continue to improve.

\section{Methodology}

In this research, a production function is used to establish the empirical link between the ICT capital used by banks and their production level. Microeconomic theory of production provides a number of theoretical models of a firm's production function for empirical analysis. Examples include Cobb-Douglas, Leontief, CES ${ }^{3}$, Linear Programming and Translogarithmic production functions. The most commonly used in empirical research are the Cobb-Douglas production function and the translogarithmic production function. However, these two functions are not individually free of limitations.

The Cobb-Douglas function is based on restrictive assumptions, including those of substitutability and the unit elasticity of substitution of production factors. The substitutability assumption assumes that all factors of production used in the production process are substitutable for each other, which is not necessarily the case in reality $^{4}$. To relax these restrictive assumptions, a flexible (translogarithmic) function is proposed in the literature in place of the Cobb-Douglas function. It is the general case of the Cobb-Douglas production function. The latter is also not without its limitations. Indeed, any production function must respect the regularity conditions ${ }^{5}$ of neoclassical theory. The Cobb-Douglas function respects them. On the other hand, there is no certainty for the translogarithmic function to respect these conditions while maintaining its flexibility. This research adopts the Cobb-Douglas production function for the reason that it meets with certainty the regularity conditions of a production function and that, although restrictive, the assumptions underlying it may hold more if the factors of production (ATMs, labor and physical capital) are combined in the same production process.

3.1. Theoretical form of the Cobb-Douglas production function

The theoretical form of the production function of Cobb and Douglas (1928) is as follows:

$Y_{i t}=A f\left(K_{i t}, L_{i t}\right)=A K_{i t}^{\beta_{1}} L_{i t}^{\beta_{2}}$

With $\beta_{1}, \beta_{2}<1$ and $\beta_{1}+\beta_{2}=1$; the conditions of substitutability of labor and capital factors.

Where: $Y$ represents the output level of the firm; $A$ is the exogenous factor of the model; $K$ represents the capital factor and the labor factor and $L$ is the labor factor. $K$ and $L$ constitute the inputs of the model. $i$ and $t$ represent respectively the individual and temporal dimensions of the model. 


\subsection{Extension of the Cobb-Douglas production function}

The production function in (1) can be extended in its arguments by adding new factors of production to the two traditional factors. Barro (1990) did so by adding public capital as a third factor in the production function alongside the traditional private factors. In the empirical literature, authors such as Kilicaslan et al (2015) and Mitra et al (2016) have also adopted the same methodology by including ICT as a third factor of production in the Cobb-Douglas model and finally analyzing its effects on output or factor productivity. This analysis is consistent with the same logic and model (1) becomes:

$Y_{i t}=A f\left(K_{i t}, L_{i t}, T_{i t}\right)=A K_{i t}^{\beta_{1}} L_{i t}^{\beta_{2}} T_{i t}^{\beta_{3}}$

With now $\beta_{1}, \beta_{2}, \beta_{3}<1$ and $\beta_{1}+\beta_{2}+\beta_{3}=1$

Where T represents the ICT variable, the other variables having already been defined at the model level (1). The application of the logarithm to model (2) leads to the empirical model of the present research, which is written as follows:

$\ln \left(Y_{i t}\right)=\beta_{0}+\beta_{1} \ln \left(L_{i t}\right)+\beta_{2} \ln \left(K_{i t}\right)+\beta_{3} \ln \left(T_{i t}\right)+\varepsilon_{i t}$

Where $\ln$ is the logarithm of the variables, $\beta_{0}=\ln A$ represents the model constant and $\varepsilon$, the model error term. The parameters $\beta_{j}$ are the elasticities of the variables with which they are associated.

\subsection{Definition of the variables of the empirical model}

In general, the production function applies without great difficulty to ordinary companies. However, its transposition to the banking firm is subject to a number of difficulties. Unlike the ordinary firm, which is a singleproduct firm, the bank is a multi-product firm, which makes it difficult to analyze its output. In its activities, the bank combines flow variables and stock variables, which also requires some attention to the nature of the variables to be used as outputs and inputs in the analysis of its production function. Referring to Sealey and Lindley (1977), it is apparent that there is no consensus in the literature on what constitutes the bank's "output" and "input. This divergence in the definition of the output and input of the bank is such that, in the literature, some authors, such as Benston (1972) and Mackara (1975), indicate that the researcher can adopt any measure of these variables as long as it is consistent with the purpose of the research.

This analysis shares the view of Sealey and Lindley (1977) of what should be a theory of the production of a banking firm. The authors developed the concepts of outputs, inputs, function, and cost of production of financial institutions by taking into account the particularity of a financial firm compared with an ordinary firm. They have also done so by shaping their methodological approach so that it is as comparable as possible to other approaches that applied microeconomic theory uses to define the same concepts in other areas of production.

On balance, the authors define the bank on the basis of its traditional role of intermediation between agents with financing capacity and those in need of financing. Between the two categories of economic agents, the bank ensures a transformation process in the middle. Sealey and Lindley (1977) argue that the production process of the financial firm is a multi-stage production process. It involves intermediate products (loanable funds or bank deposits), collected from savers and served by the financial firm with the use of capital, labor and materials (as inputs), in the production of remunerated assets that constitute the output or output. Following these clarifications, it is possible to define the set of variables in the model (3).

3.3.1. Model-dependent variable

$Y$ is the model-dependent variable. This output groups together all the bank's remunerated assets, following the logic of Sealey and Lindley (1977). In the accounting system applied to WAEMU banks, the bank's interestbearing assets can be summarized as interbank claims, claims on customers and investment securities.

3.3.2. Model-independent variables

The independent variables of the model are labor $(L)$, non-technological physical capital $(K)$, technological capital $(I C T)$. Labor is measured by the number of bank staff. Capital is measured by the bank's fixed assets. Fixed assets are the sum of tangible and intangible fixed assets. As for ICT, this research measures it by the sum of automated teller machines (ATMs). The indicator that best measures ICT is the total investment of banks in computer hardware and software. However, data on this indicator are not available at the level of the WAEMU banking system. One of the conditions for the regularity of a neoclassical production function is the positivity of the marginal productivities of the factors of production. This condition guarantees the existence of a positive sign between each input, L, K and ICT, and the total output. Therefore, the variables L, K and ICT are all positively related to $Y$.

The mechanism by which the use of ATMs technology will particularly affect the level of production of banks can be explained by the particular role that this technology plays alongside other factors of production and also by the effects that the use of this technology can have on banks' operating costs. While ATMs only allow bank customers to make liquidity withdrawals, ATMs on the other hand offer more transactions to their users. Depending on the model considered, ATMs allow, among other things, to make withdrawals, to make cash or cheque deposits, to order funds transfers, to reload prepaid bank cards, to offer account positions. This 
digitalization of banking services to the population contributes to reducing the operating costs of banks (Daley, 2003; El Fidha and Charki, 2008). A reduction in banks' operating costs is likely to boost their ability to improve their level of production of banking services.

The automation of the offer of these banking services to customers also makes it possible to relieve some of the burden on the bank staff who act as the interface between the bank and its customers. In this sense, the use of ATMs offers banks the possibility of freeing up margin on the labor factor and reallocating this margin to the production of other services requested by their customers. In the absence of reallocating the work margin, banks may opt to substitute some bank staff for ATMs. These are specifically the staff who deal with cash operations and whose tasks are largely automated at the ATMs level. However, such a substitution requires that the main method of cash withdrawal and deposit for the banking population in the Union be ATMs. This substitution logic, if viable, offers banks the possibility of reducing their operating costs by reducing staff costs. The reduction of production costs alleviates the banks' production constraint and is therefore likely to improve their production level. Moreover, as counters, ATMs are likely to improve the banks' capacity to mobilize financial resources from the population. The logic being that populations are more motivated to save with banks if they know that there are facilities to access these savings when needed. Thus, the use of ATMs by banks can contribute to the mobilization of financial resources, and thus to the improvement of the banks' production capacity.

\subsection{Data source and sample presentation}

The data used in this research come from the 2018 statistics of the Central Bank of West African States (CBWAS). The sample used in this research is made up of aggregate data from the banks of the eight WAEMU countries. The data on the variables of the model (3) were filled in for each of the eight countries of the Union over the period 2010-2016. The choice of the analysis period is due to the fact that data on ATMs are only available for this period at the time of the study. The panel is cylindrical. It is characterized by relatively small temporal and individual dimensions. The choice of the estimation method for the model (3) must necessarily also take into account this characteristic of the sample in order to arrive at better estimators.

\subsection{Choice of estimation method}

In order to obtain better econometric results, some specification tests were first conducted on the empirical model. These are the stationarity test of the model variables and the correlation test between the model variables. It emerged from these tests that, on the one hand, all the variables of the model (3) are level stationary and, on the other hand, all the variables are correlated with each other. Taking into account the order of integration of the variables in a regression avoids the problem of spurious regression. The existence of correlation between the explanatory variables is a source of multicollinearity when these variables are used together in the same estimation. To overcome problems of multicollinearity, autocorrelation and heteroskedasticity of errors, this research uses the Panel-Corrected Standard Errors (PCSE) estimator to estimate the model (3). Moreover, given that the sample size of the research presence is small and that the individual dimension of the data is not worth at least twice their time dimension, this econometric method appears to be one of the most appropriate for estimating model (3) according to Beck and Katz (1995). The standard error-corrected panel estimator is directly integrated into some econometric software such as Stata, version 12 of which was used to estimate the empirical model for this research.

\section{Results and Interpretations}

4.1. Descriptive data analysis

Descriptive analysis identifies the mean, minimum and maximum values, standard deviations, and relative dispersion of the data around the mean of the variables in the research model. The results of the descriptive statistics of the model variables (3) are reported in Table 1 below:

Table 1: Descriptive Statistics of Sample Data

\begin{tabular}{l|ccccc}
\hline Variables & Average & Standard deviation & Minimum & Maximum & $\mathrm{CV}^{*}$ \\
\hline Bank claims & $2.2 \mathrm{e}+12$ & $1.7 \mathrm{e}+12$ & $9.1 \mathrm{e}+10$ & $8.2 \mathrm{e}+12$ & 0.76 \\
Capital & $9.3 \mathrm{e}+10$ & $7.2 \mathrm{e}+10$ & $3.9 \mathrm{e}+09$ & $2.8 \mathrm{e}+11$ & 0.77 \\
Labor & $2,835.28$ & 1917.18 & 224 & 8044 & 0.67 \\
ATMs & 274.857 & 212.836 & 13 & 934 & 0.77 \\
\hline
\end{tabular}

Note: $\mathrm{CV}=$ Coefficient of variation

From Table 1, it can be seen that in the WAEMU, the average amount of bank claims over the period 20102016 was 2270 billion F CFA. The average amount of tangible and intangible fixed assets, representing the monetary value of the physical capital of banks in the Union, was 93.2 billion F CFA over the 2010-2016 period. The average number of bank staff in the Union over the same period was 2835.

The average number of ATMs was 275 in the Union over the 2010-2016 period. The relative dispersion around the average of the values of each variable is relatively high, with a coefficient of variation above $67 \%$ for each of the variables in the model. At the econometric level, highly volatile data could influence the precision of 
the estimators. However, the use of the logarithm smoothies highly volatile data and thus avoids possible drawbacks of data volatility on the precision of the estimators.

4.2. Presentation and discussion of results

Table 2: Model estimation results (3)

\begin{tabular}{lcc}
\hline \multirow{2}{*}{ Bank claims } & \multicolumn{2}{c}{ PCSE } \\
\cline { 2 - 3 } & Coefficients & Z-statistics \\
\hline Capital & $0.683^{* * *}$ & 6.09 \\
Labor & $0.424 * * *$ & 2.92 \\
ICT & $0.219^{* * *}$ & 3.75 \\
Constant & $8.848^{* * *}$ & 5.03 \\
\hline Number of observations & 56 \\
Adjusted R & \multicolumn{2}{c}{0.9990} \\
Rhos & \multicolumn{2}{c}{0.6960} \\
Wald test statistic & Prob $>$ Chi2 $=0.0000$ \\
\hline
\end{tabular}

*** denotes the significance of the coefficients at $1 \%$.

The validation statistics for the results of the model (3) are satisfactory overall. Adjusted $\mathrm{R}^{2}$ is $99.90 \%$. The Chi2 P-value of the Wald statistic is less than 5\%. This indicates that the model is globally exhaustive. The Rho statistic is 0.696 . In view of this relatively high value of the Rho statistic, it appears that the correction for autocorrelation is not negligible in the estimate that has been made. Taken together, these statistics indicate that the results obtained with the PSCE estimator are statistically valid and can be interpreted accordingly.

The results of the empirical model estimation in this research show that capital, labor and ATMs all positively and significantly influence the level of bank claims. These results show that a $1 \%$ increase in the number of bank ATMs in an Union country leads to a $0.219 \%$ increase in the volume of bank claims in that country over the period 2010-2016. In view of this result, the hypothesis of the present research that bank ATMs significantly improve their level of production is confirmed. Thus, the results of this research show that there is no paradox in the Solow output of the use of ATMs in the WAEMU banking sector. Similarly, over the same period, a change in the quantity used of one of the two classical factors of production (labor and capital) leads to a change in the volume of banking output in the WAEMU in the same direction.

At the theoretical level, this result of the positive and significant effect of bank ATMs on the level of bank output in the WAEMU is consistent with Schumpeter's (1939) theory of technological innovation. Indeed, this theory suggests that the use of a new production technology by a firm is a source of improvement in its level of output or productivity. The results also show that the empirical effects of the use of ATMs on the level of production of banks in the Union are in line with the anticipated theoretical effects that logically led the same banks to adopt and use this technology in their business according to the theoretical analysis of Venkatesh et al (2003).

Empirically, this result of the positive and significant effect of ATMs on the level of output of banks in the WAEMU is similar to that found by Martín-Oliver and Salas-Fumás (2008). These authors found that the increase in the ICT capital stock accounted for one-third of the increase in output of Spanish banks over the period 19832003. It is also consistent with the research findings of Mehmood et al (2015) who found that ICT have a positive impact on the output of Pakistan's banking sector over the period 2006-2013. Overall, this result is consistent with empirical analyses that have found beneficial effects of ICT on the overall performance of banks that use them (Monyoncho, 2015; Muhammad et al, 2013; Ogunyomi and Obi, 2016; Shu and Strassmann, 2005).

\section{Conclusion and implications}

The aim of the research was to analyze the effects of information and communication technologies on the performance of banks in the West African Economic and Monetary Union. Its contribution consisted in testing the validity of Solow's (1987) production paradox on the WAEMU banking sector. For the empirical verification of the relationship between the use of ATMs by banks in the Union and their level of production of customer banking services, a Cobb-Douglas production model was used. The model was estimated by the panel-corrected standard error estimator over the period 2010-2016.

The results of the model showed that the technological capital of banks in the Union has a positive and significant influence on their level of output over the period 2010-2016. The research hypothesis was confirmed. It emerges that Solow's (1987) paradox is invalidated regarding the effects of the use of ATMs on the level of production of banks in the WAEMU. The objective of this research was achieved.

This research encourages the use of ATMs by banks in the WAEMU. The reason is that their use contributes to strengthening the level of production of banks in the Union. It also encourages the BCEAO in mobilizing more statistics, at least aggregated, on the use of ICT in the banking sector in the WAEMU. These include, for example, statistics by country on the monetary volume of transactions carried out through ATMs and e-banking in the Union, 
and statistics on banks' investments in computer hardware and software. The availability of these data will enable researchers to deepen their research on the effects of the process of digitalization of banking services to the public on the performance of the Union's banking sector in particular and on the Union's economy in general.

\section{References}

Akhisar, I., Tunay, K. B., et Tunay, N. (2015). The Effects of Innovations on Bank Performance: The Case of Electronic Banking Services. Procedia - Social and Behavioral Sciences 195, 369-375.

Alderete, M., \& Gutiérrez, L. (2012). TIC y productividad en las industrias de servicios en Colombia. Lecturas de Economía, No. 77, 163-188.

Algan, Y., Bacache-Beauvallet, M., et Perrot, A. (2016). Administration numérique. Notes du conseil d'analyse économique, $n^{\circ} 34,1-12$.

Barro, R. J. (1990). Government Spending in a Simple Model of Endogeneous Growth. The Journal of Political Economy, Vol. 98, No. 5, Part 2: The Problem of Development: A Conference of the Institute for the Studt of Free Enterprise Systems, S103-S125.

Beccalli, E. (2007). Does IT investment improve bank performance? Evidence from Europe. Journal of Banking \& Finance, 2205-2230.

Beck, N., et Katz, J. N. (1995). What to do (and not to do) with Time-Series Cross-Section Data. The American Political Science Review, Volume 89, 634-647.

Benston, G. J. (1972). Economies of Scale of Financial Institutions. Journal of Money, Credit, and Banking, IV, $312-334$

Binuyo, A. O., et Aregbeshola, R. A. (2014). The impact of information and communication technology (ICT) on commercial bank performance: evidence from South Africa. Problems and Perspectives in Management, Volume 12, pp. 59-68.

Cobb, C. W., et Douglas, P. H. (1928). A Theory of Production. The American Economic Review, Vol. 18, No. 1, $139-165$.

Daley, N. (2003). Les TIC et la banque de détail. Perspectives et enjeux. Les Cahiers du numérique, Vol. 4, 115 129.

Davis, F. D. (1989). Perceived Usefulness, Perceived Ease of Use, and User Acceptance of Information Technology. MIS Quarterly, Vol. 13, 319-340.

Donati, C., \& Sarno, D. (2013). The impact of ICT on productivity of Italian firms: evaluation of the microcomplementarity hypothesis. Applied Economics Letters, 349-352.

El Fidha, C., et Charki, M. H. (2008). « Le rôle des technologies de l'information et de la communication dans le développement de la qualité de la « relation client». Application à la relation banque/entreprise ». Revue des sciences de gestion, $n^{\circ} 229,121-127$.

Gordon, R. J. (2000). Does the "New Economy" Measure up to the Great Inventions of the Past? Journal of Economic Perspectives, Volume 14, Number 4, 49-74.

Hall, B. H., Lotti, F., \& Mairesse, J. (2012). Evidence on the impact of R\&D and ICT investments on innovation and productivity in Italian firms. Economics of Innovation and New Technology, 1-29.

Ho, S. J., et Mallick, S. K. (2010). The Impact of Information Technology on the Banking Industry. The Journal of the Operational Research Society, Vol. 61, No. 2, 211-221.

Ibrahim, S. S., et Muhammad, A. (2013). Information and Communication Technology and Bank Performance in Nigeria: A Panel Data Analysis. Munich Personal RePEc Archive.

Kilicaslan, Y., Sickles, R. C., Kayis, A. A., et Gurel, Y. U. (2015). Impact of ICT on the Productivity of the Firm: Evidence from Turkish Manufacturing. RISE Working Paper 15-017.

Mackara, W. F. (1975). What Do Banks Produce? Monthly Review, Federal Reserve Bank of Atlanta, LX, 70-74.

Martín-Oliver, A., et Salas-Fumás, S.-F. V. (2008). The output and profit contribution of information technology and advertising investments in banks. Journal of financial intermediation 17, 229-255.

Mehmood, B., Nisar, A., et Ur Rehman, H. (2015). Technology matters: Evidence from Pakistani banking sector using flexible transcendental logarithmic production function. Pakistan Economic and Social Review, Volume 53, No. 2, 203-224.

Mitra, A., Sharma, C., et Véganzonès-Varoudakis, M.-A. (2016). Chapitre 2: Infrastructure, ICT and firm's productivity and efficiency: an application to the Indian manufacturing. Dans F. De Beule, et K. Nayaranan, Globalization of Indian Industries: Productivity, Exports and Investment (pp. 17-41). Singapore: Springer.

Monyoncho, L. N. (2015). Relationship between banking technologies and financial performance of commercial banks in Kenya. International journal of economics, commerce and management, Vol. III, 784-815.

Muhammad, A., Gatawa, N. M., et Kebbi, H. S. (2013). Impact of information and communication technology on bank performance: A study of selected commercial banks in Nigeria (2001-2011). European Scientific Journal, vol.9, No.7, 213-238.

Ogunyomi, O. O., et Obi, E. (2016). Information and Communication Technology Investment and Firm 
Productivity: Evidence from the Nigerian Banking Industry. Research Journal of Finance and Accounting, Vol.7, No.8, 47-59.

Rogers, E. M. (1962). Diffusion of innovation. New York: Free Press of Glencoe.

Schumpeter, J. A. (1911). The theory of economic development. Cambridge: MA: Harvard University Press.

Schumpeter, J. A. (1939). Business cycles: A theorical, historical and statistical analysis of the capitalist process. London: McGraw-Hill Book Company.

Sealey, C. W., et Lindley, J. T. (1977). Inputs, outputs, and a theory of production and cost at depository financial institutions. The Journal Of Finance, Vol. XXXII, No. 4, 1251-1266.

Shu, W., et Strassmann, P. A. (2005). Does information technology provide banks with profit? Information \& Management 42, 781-787.

Solow, R. M. (1956). A contribution to the theory of economic growth. Quaterly journal of economics, Vol. 70, $n^{\circ} 1,65-94$.

Solow, R. M. (1987). "We'd better watch out.". New York Times Book Review, p.36.

Swierczek, F. W., et Shrestha, P. K. (2003). Information technology and productivity: a comparison of Japanese and Asia-Pacific banks. Journal of High Technology Management Research 14, 269-288.

Venkatesh, V., Moris, M. G., Davis, G. B., et Davis, F. D. (2003). User acceptance of information technology: Toward a unified view. MIS Quarterly, Vol. 27, 425-478.

\section{Notes}

Note 1. WAEMU means West African Economic and Monetary Union. It includes eight West African countries: Benin, Burkina Faso, Côte d'Ivoire, Guinea-Bissau, Mali, Niger, Senegal and Togo.

Note 2. These statistics come from the various reports of the WAEMU Banking Commission from 2010 to 2016.

Note 3. Constant Elasticity of Substitutions.

Note 4. In an airline company, in order to provide a flight service to customers, the flight crew cannot be substituted for the flying aircraft and vice versa. In such cases, production factors are complementary and not substitutable.

Note 5. Positivity of marginal productivities of factors of production; Decreasing yields; isoquant convexity and negative eigen elasticities of factors.

Note 6. Calculated by the author using the following formula: Adjusted $R^{2}=1-\left(1-R^{2}\right) \frac{n-1}{n-K-1}$ , with $\mathrm{n}=$ number of observations and $\mathrm{K}=$ number of explanatory variables of the model. 